\title{
CO WIEMY O LIRYCE NORWIDA? KILKA UWAG O SPOSOBACH CZYTANIA POETY ${ }^{1}$
}

\author{
Napisał Norwid we wstępie do Kleopatry i Cezara:
}

„rym b i a ły, bez końcówek, jest daleko trudniejszym do pisania aniżeli wiersz końcowany i wiązany, z tej przyczyny, iż on jest wiązany nie tylko samą i w jednym punkcie końcówką, lecz na całej swej długości. Wiersz niewiązany wiele więcej od wiązanego wymaga poprawności."”

Rozpoczynam od przypomnienia takiej świadomości Norwida, która z wyrazistością i mocą wskazuje na mowę poezji jako tę nadzwyczajnie zorganizowaną, również w tych miejscach, gdzie nie sięga już rym i „pierwszoplanowy” rytm, osobny kształt poszczególnych tropów, i - co oczywiste - zespół norm gramatycznych, językowych. Albo - sięgają, ale w sposób już tak przetworzony, że nie sposób dopatrzeć się ich pierwotnego kształtu. Z literaturoznawców drugiej połowy XX w. najbliższe Norwidowi poglądy w tej materii wyraził chyba Ireneusz Opacki, twierdząc, i to we wstępie do interpretacji Słowackiego (poety o nadzwyczaj trudnej do określenia naturze liryczności), że rzeczywistość poezji ,jest dziedziną wyobraźni ścisłej”. ${ }^{3}$ Norwid zaś, zwłaszcza w ostatnim przywołanym zdaniu, o tym, że wiersz „niewiązany wiele więcej od wiązanego wymaga

${ }^{1}$ Tekst został wygłoszony na sympozjum w Uniwersytecie Kardynała Stefana Wyszyńskiego, poświęconym problemom badań nad Norwidem: Jak czytać Norwida? Postawy badawcze, metody, weryfikacje (15-16 grudnia, 2005, Warszawa). Gatunkowo sytuuje się na pograniczu komunikatu.

${ }^{2}$ Wszystkie zacytowania Norwida pochodzą z wydania: Cyprian Norwid, Pisma wszystkie. Zebrał tekst ustalił, wstępem i uwagami krytycznymi opatrzył Juliusz Wiktor Gomulicki, t. I-XI, Warszawa 1971-1976; tu: V, s. 9-10.

I. Opacki, „W środku niebokrega”. Poezja romantycznych przełomów, Katowice 1995, s. 8 . 
poprawności", akcentuje nadzwyczajną spoistość utworu poetyckiego i reguły rządzące tą spoistością.

Jeśli chcę mówić na temat „co wiemy o liryce Norwida”, to nie chodzi, oczywiście, o przywoływanie rezultatów ogromnych badań, trwających niemal wiek, które doprowadziły do pewnej przejrzystości tematów, pojawiających się w liryce Norwida, wyszczególniły gatunki, powiązały problematykę wierszy z realiami życia poety, zabudowały puste pole kontekstów historycznoliterackich (np. Norwid wobec pierwszej fali romantyzmu i wobec tendencji pozytywistycznych), rekonstruowały wizję człowieka, obecną w jego poezji, czy, jak to się mówi ostatnio: antropologiczny wymiar tej twórczości.

Istnieją w obrębie zarysowanych pól prace wybitne, nie zdezaktualizowane i, jak możemy przewidywać, żywe będą jeszcze przez wiele dziesięcioleci. Istnieją również mniej trafne rozpoznania, ale poprzez swoją obecność tak korzystnie dla norwidologii rysujące granice możliwych obserwacji i ustaleń, że zyskujemy pewniejsze rozeznanie dokąd pójść można, a gdzie absolutnie chodzić nie należy. $Z$ perspektywy odległego czasu dostrzegamy, że np. wielka surowość Wacława Borowego wobec Romana Zrębowicza działała oczyszczająco na metodę ${ }^{4}$, ale niejednokrotnie przyćmiewała celne intuicje pisarza dotyczące natury poezji Norwida.

Ostatnie, ekspresywnie inteligentne prace Wiesława Rzońcy, nie zawsze trafne w swoich ostatecznych konkluzjach, tym mocniej pokazały, jak silne jest to wewnętrzne „constans” poety, nie podatne na żadne metodologiczne ,próby”. ${ }^{5}$

Formalistyczno-strukturalistyczna rewolucja w literaturoznawstwie, inaczej mówiąc, istotne usprawnienie metody lektury poezji w ogóle, stworzyło również określone możliwości dla badaczy wiersza Norwida. Pośrednim wykorzystaniem tej możliwości była (przykładowo) monografizująca praca Zdzisława Łapińskiego ${ }^{6}$, również, między wieloma innymi, interpretacje z tomu Stanisława Makowskiego Cypriana Norwida kształt prawdy i miłości ${ }^{7}$, a także całkiem

\footnotetext{
${ }^{4}$ Zob. np. W. Borowy, Norwidiana 1921-1924, [w:] O Norwidzie. Rozprawy i notatki, Warszawa 1960, s. 99-100.

${ }^{5}$ Zob. np. W. Rzońca, Norwid poeta pisma. Próba dekonstrukcji dzieła, Warszawa 1995.

${ }^{6}$ Z. Łapiński, Norwid, Kraków 1971 (i wyd. następne).

${ }^{7}$ Cypriana Norwida Ksztalt prawdy i miłości. Analizy $i$ interpretacje, pod red. St. Makowskiego, Warszawa 1986.
} 
niedawno Aleksandry Okopień-Sławińskiej czytanie wiersza Jak... w „Tekstach Drugich”. ${ }^{8}$

Pośród wielości komentarzy do poszczególnych utworów Norwida ${ }^{9}$, tych najdoskonalszych omówień, w których świadomie i do końca udatnie wykorzystuje się zasoby metodologiczne aktualnych albo nie przewartościowanych w danym momencie teorii literaturoznawczych, pozostaje i widoczny jest pewien niedostatek; pewna „wierszowa różnica”, której nie udaje się wychwycić interpretatorom.

Bywało, że istotna różnica - jeśli ukryty w niej został finezyjny, ale zasadniczy sens wiersza.

Mówię w tej chwili o sytuacji, kiedy badacz zajmie się już i dokładnie scharakteryzuje np. paraboliczność utworu, jego charakter wersyfikacyjny, genologiczne powikłania i historycznoliterackie okoliczności, a nawet dokona mrówczej analizy sensów, uruchamiając aparat filozoficzny. Wszyscy doskonale pamiętamy świetną analizę Fortepianu Szopena pióra Władysława Stróżewskiego, to refleksyjne skupienie na każdym słowie, pogłębienie jego rozumienia poprzez uruchomienie wiązek znaczeń, ujawnienie niezwykłej wrażliwości na muzyczny rytm i wymiar tekstu. ${ }^{10}$ Ale ostatecznie przyznać musimy, jeśli zdaliśmy się kiedykolwiek na własną lekturę tego wiersza-poematu, że jest to doskonała analiza filozofa reaktywującego przede wszystkim znaczenia, analiza bardzo ważna, jeśli połączyć ją z tym, co o Fortepianie Szopena napisali do tej pory poloniści (np. Tadeusz Makowiecki ${ }^{11}$ ); ale analiza pozostawiająca namiastkę niedosytu - mimo trudu badacza w procesie dążącym do integralnego zobaczenia całości - czegoś tu brakuje. I znów nie chodzi mi o banalne, bo powszechnie znane doświadczenie, że tekst wiersza nie daje się przełożyć na dyskurs, chodzi o to, że coś jeszcze dałoby się na język tzw. naukowego opisu przełożyć, że istnieje dalszy ciąg opisywanej rzeczywistości wierszowej, tylko wymaga on trudu badawczego i przytomnej intuicji (być może rezygnują-

\footnotetext{
${ }^{8}$ A. Okopień-Sławińska, Semantyczna strategia zamilczenia (Przypadek „Jak...” Cypriana Norwida), „Teksty Drugie” $2000 \mathrm{nr} 5$.

${ }^{9}$ Zebrano je w: Bibliografia interpretacji wierszy Norwida, oprac. A. Cedro, P. Chlebowski, J. Fert przy współudziale M. Busia i J. Leociaka, Lublin 2001.

${ }^{10} \mathrm{~W}$. Stróżewski, Doskonate - wypetnienie. O „Fortepianie Szopena” Cypriana Norwida, [w:] Istnienie i wartość, Kraków 1981.

${ }^{11}$ T. Makowiecki, ,Fortepian Szopena”, [w:] O Norwidzie pięć studiów, Toruń 1949.
} 
cej z obciążenia jakąkolwiek bądź metodologią), projektującej horyzont zamierzeń.

Przejdźmy do konkretów:

Jak gdy kto ciśnie w oczy człowiekowi

Garścią fijołków i nic mu nie powié...

Jak gdy akacją z wolna zakołysze,

By woń, podobna jutrzennemu ranu,

$\mathrm{Z}$ kwiaty białymi na białe klawisze

Otworzonego padła fortepianu...

(II, 82)

Fragment dobrze znanej całości; tę całość chcę respektować. Aleksandra Okopień - Sławińska rozpoczyna analizę wiersza od „idei milczenia jako składnika i stymulatora mowy”, pyta m.in.: „Co tu zostało powiedziane, a co zamilczane?” i stwierdza, że wiersz „oparty [jest] na schemacie niezrealizowanego porównania, w którym czterokrotnie powtarzają się człony porównujące, a zamilczany zostaje człon porównywany..."

Całe jej dalsze postępowanie, wracające rytmicznie, co jakiś czas do tekstu Norwida, w dużym stopniu pozostaje na obszarze jednak jakichś makrostruktur, podporządkowane bardziej określonemu, pozatekstowemu zamysłowi (semantycznej strategii poetyckiego zamilczenia), aniżeli samemu komunikatowi lirycznemu. "Zamilczenie" jest jednym ze składników dzieła. $\mathrm{O}$ tak ważnym estetycznie pierwszym dwuwersie mówi się tu, że

Rzucenie w kogoś fiołkami jest gestem zaczepki pełnej uroku, tu jednak mowa o rzuceniu w o c z y [...] g a r ś c i ą fiołków, co jest już aktem gwałtowniejszym, prowokującym, być może nie całkiem przyjaznym i krotochwilnym, nie wiadomo więc jakim, zwłaszcza, że nie towarzyszy mu żadne wyjaśnienie słowne. ${ }^{13}$

Autorka świetnej analizy, a jednak, kiedy widzimy ją (tę analizę) w zbliżeniu, samą w sobie, przechodzi do interpretacyjnego porządku (rytmu postępowania) zbyt szybko, uwzględniając tylko pewien szkielet zdarzenia lirycznego. Na przykład: „rzucać” to

\footnotetext{
${ }^{12}$ A. Okopień-Sławińska, Semantyczna strategia zamilczenia..., op. cit., s. 31-32.

${ }^{13}$ Tamże, s. 34.
} 
jednak coś innego niż „cisnąć” i jeśli w komentarzu pominiemy tę subtelną różnicę jakaś prawda o wierszu pozostanie niezauważona (mieści się tu i gwałtowność wyrazu, i emocjonalno-tradycyjny bagaż tego słowa, i jeszcze coś więcej, jakaś zamaszystość gestu, połączona $\mathrm{z}$ niezwykłą delikatnością - obecne w warstwie wyglądów). Na zasadnicze modelowanie znaczeń w tym początkowym fragmencie wpływają dwa punkty wyglądowo-znaczeniowe: „cisnąć" i „garścią fijołków”. „Nic mu nie powie” natomiast nie posiada wyraźnego „wyglądowego" podkładu albo jest on bardzo niepozorny, nieznaczny...

Natomiast „brak słów” i to wielkie miejsce niedookreślenia, zaakcentowane zostaje dzięki brzmieniom, modyfikowanym (wzmacnianym) przez rym. Co z tych uwag wynika? Również i to, że charakterystyczna jakość - estetycznie walentna, jak powiedziałby Ingarden - powstaje w związku z aparatem percepcyjnym czytelnika i uwalnia go niejako od troski „kto”, „w jakim celu” i „dlaczego”; nie każe temu czytelnikowi koncentrować się na wielkim, białym polu niedookreślenia, ale właśnie na sugestii (wrażeniu), związanym z tym, co powiedziane. A co zostało powiedziane? On, bohater wiersza (podobnie jak czytelnik) nic nie usłyszał, „nic mu nie powiedziano", więc jego bezradność, bez-siła, składają się ostatecznie na pewną jakość zbliżoną do smutku (czy smętku potwierdzonego ostatnim wersem).

W ten sposób podeszliśmy do centralnej dla liryki kategorii podmiotu lirycznego, jego promieniowania (tzn. wysyłania „nitek emocjonalnych" na cały tekst).

$\mathrm{Z}$ intuicją pomijającą podobny tryb postępowania wychwyciła tę sytuację znakomicie Danuta Zamącińska, stwierdzająca po prostu:

Norwid [...] powiedziawszy wszystko co trzeba metodą poety - dodaje: „[...] lecz nie rzeknę nic - bo mi jest smętno”. Jak to „nie rzeknę nic" - pyta czytelnik - skoro aż tyle rzekłeś i przecież od pierwszej linijki widzę, że ci smętno"! !4

Komentuje to stwierdzenie Aleksandra Okopień Sławińskanie do końca godząc się z cytowaną autorką opisu Norwidowego wiersza:

${ }^{14}$ D. Zamącińska, Stynne-nieznane. Wiersze późne Mickiewicza, Stowackiego, Norwi$d a$, Lublin 1985, s. 81. 
Rzecz w tym, że zadaniem, z którym borykał się mówiący, nie było uporczywe wyrażanie własnego smutku, ale dążenie do wypowiedzenia odczuć niewyrażalnych. ${ }^{15}$

Obie postawy badawcze zupełnie się nie wykluczają, różnica jest tylko taka, że Danuta Zamącińska pozostaje ściśle przy wierszu, jej osąd interpretacyjny jest rezultatem stworzenia odpowiedniego dystansu badawczego na skutek dającego się określić promieniowania całej zawartości Norwidowego tekstu, Aleksandra Okopień-Sławińska natomiast rozpoczyna i kończy ogląd, posługując się nieprzystającą do końca do utworu kategorią niewyrażalności, wyprowadzoną z wymiaru sensów, która nie odpowiada pełni brzmieniowo-wyglądowo-znaczeniowej utworu.

Istnieje cenny tekst Romana Ingardena o funkcjach artystycznych języka, w którym filozof i fenomenalny znawca natury twórczości lirycznej pokazuje grę jakości estetycznych w inwokacji do Pana Tadeusza $a^{16}$. Chodzi tam w zasadzie tylko o jedno, pośrednio oczywiście, jak przekroczyć strukturalistyczną barierę (brzmi to może trochę paradoksalnie) i pójść dalej, tzn. głębiej w rozpoznawaniu tekstu literackiego, języka zorganizowanego artystycznie.

Szkic filozofa dotyczy pewnego „wycinka” rzeczywistości tekstowej (tekstu artystycznego), ponieważ istnieją pozajęzykowe składniki dzieła, tzn. przedmioty przedstawione i wyglądy, które wcześniej zostały przeze mnie wprowadzone do refleksji.

Pisze Ingarden:

to nie znaczy, jakoby brakowało studiów nad językiem dzieł literackich [...]. Chodzi o to, że przy lekturze dzieła w postawie estetycznej pojawiają się w jego konkretyzacji pewne jakości, które same w sobie nie są elementami czy momentami tworów językowych, ale które obecnością swą w całości dzieła - głównie w warstwie przedmiotów przedstawionych i w wyglądach - sprawiają, iż stanowią one podbudowę wartości estetycznej dzieła [...] I zagadnienie polega na tym, by po zdaniu sobie sprawy, jakie to jakości tego rodzaju w danym dziele występują, zapytać, od jakich właściwości języka, czy tworów językowych, zależy ich naoczne pojawienie się $\mathrm{w}$ dziele ${ }^{17}$

\footnotetext{
${ }^{15}$ A. Okopień-Sławińska, Semantyczna strategia ..., op. cit., s. 38.

${ }^{16}$ R. Ingarden, Funkcje artystyczne jezyka, [w:] tegoż, Studia z estetyki, t. III, Warszawa 1970.

${ }^{17}$ Tamże, s. 316-317.
} 
i gdzie indziej:

U podstaw tej próby [zbudowania nowej perspektywy badania funkcji artystycznych języka] leży przeświadczenie, iż jakości estetycznie doniosłe faktycznie pojawiają się przy estetycznym konkretyzowaniu literackich dzieł sztuki i że one to odgrywają wielka rolę przy ujawnianiu się estetycznej wartości w poszczególnych dziełach. ${ }^{18}$

I jeszcze dość kluczowy dla mnie sąd fenomenologa o tych postawach badawczych, które wykluczają podobne podejście do tekstu zorganizowanego artystycznie:

Traktują [tacy badacze] pojawienie się jakości estetycznie doniosłych jako w teorii informacji tak zwane „dudnienie” czy „szumy” i każą przechodzić nad nimi do porządku dziennego. Ułatwia to w pewnej mierze badanie dzieł literatury, ale zarazem powoduje pominięcie w nich wszystkiego, co w nich stanowi element poetycki, aspekt dzieła sztuki. ${ }^{19}$

Tutaj Ingarden wkracza na teren dla historyka literatury chyba najbardziej istotny: dotyka problemu odróżniania dzieł literackich, odrębnych osobowości twórczych odbijających się w dziele. S z u k ani e głębokiej specyficzności tekstukultury mieści się w centrum porządku poznawania w og óle.

Ta kwestia natomiast łączy się z elementarną postawą odbioru, ze sferami, w których spełnia się akt konkretyzacji. W szkicach Wiesława Juszczaka z ostatnich lat pojawia się dość radykalny wątek, odnoszący się do teorii odbioru dzieła sztuki; twierdzi autor mianowicie, że nie istnieje coś takiego jak „odbiór” (dialog, komunikacja), że można mówić jedynie o akcie twórczym, do którego dochodzi w momencie spotkania z dziełem. ${ }^{20}$ Postawa twórcza, dyspozycja wrażliwości tego, kto czyta, byłyby więc probierzem skuteczności lektury. Na marginesie można dodać, że propozycja Juszczaka przekonująco koresponduje $\mathrm{z}$ pewnymi ideami Norwida $\mathrm{z}$ Promethidiona.

\footnotetext{
${ }^{18}$ Tamże, s. 318.

${ }^{19}$ Tamże, s. 319.

${ }^{20}$ Taka myśl rozproszona jest w wielu wypowiedziach W. Juszczaka. Zob. np. jego książkę Fragmenty, Warszawa 1995, s. 45-46.
} 


\section{COLLOQUIA LITTERARIA}

Kto tak czytał lirykę Norwida? Pominę wielu, ale chcę przykładowo przywołać najwyrazistsze w moim przekonaniu przypadki.

Sporo z takiego właśnie, jak rysowałam wcześniej, czytelnika, posiadał Manfred Kridl, tak gustujacy w miniaturach Norwida; oczywiście i z ogromną wyrazistością Wacław Borowy, komentator i smakosz, autor znakomitego wyboru z poety w swojej antologii; Zofia Szmydtowa jako autorka wstępu do Liryki romantycznej" ${ }^{21}$, Stefan Szuman w analizach miniatur poetyckich ${ }^{22}$; Czesław Zgorzelski, który, jak wiadomo, Norwidem się nie zajmował, ale tych kilkanaście zdań o całościowo widzianej poezji autora Assunty jest doskonałą, trudną do prześcignięcia, pojemną syntezą, która wyrasta na konkretnej bazie twórczego aktu odbioru i projektowanego szukania swoistości tej poezji. ${ }^{23}$ Dołączyłabym tu jeszcze Ireneusza Opackiego, który, co wiadomo z prywatnych rozmów, Norwida nie lubił, ale to jego interpretacje Bema pamiecci żałobnego rapsodu ${ }^{24}$ czy wiersza $C z e m u^{25}$ nie mają sobie równych w przenikliwości widzenia najmniejszych drobin warsztatu poety, precyzji wydobywania tego, co najbardziej ulotne, a realnie w wierszu obecne.

Wreszcie przewrotny, a finezyjny i literalnie uargumentowany szkic Danuty Zamącińskiej O poznawaniu poezji Norwida. ${ }^{26}$

I jeszcze - kontrowersyjna dla wielu postawa badawcza Mariana Maciejewskiego (szkic o Malczewskim i Norwidzie ${ }^{27}$, interpretacja wiersza Fatum, $W$ Weronie). Nie chcę ustosunkowywać się do „wierzchołków” jego analiz, do tej sfery, którą przywykliśmy nazywać „teologiczną", prowokującą opinie o nadinterpretacji. Zwracam jedynie uwagę na bardzo mocne wyczulenie tego badacza na „międzywersia”, upodrzędnione i sfunkcjonalizowane oczywiście,

${ }^{21}$ Z. Szmydtowa, Liryka romantyczna, Warszawa 1947.

${ }^{22}$ S. Szuman, O kunszcie i istocie poezji lirycznej, Toruń 1948, s. 57-58.

${ }^{23} \mathrm{Cz}$. Zgorzelski, Liryczność poezji romantycznej, w: zarysy i szkice literackie, Warszawa 1988 , s. 25.

${ }^{24}$ I. Opacki, Rapsod ostatni, rapsod pierwszy, [w:] tegoż, „W środku niebokrega”. Poezja romantycznych przetomów, Katowice 1995.

${ }^{25}$ I. Opacki, Poezja romantycznych przełomów, Wrocław 1972, s. 53- 56.

${ }^{26} \mathrm{~W}$ przywoływanej już książce tej autorki; zob. przyp. 14.

${ }^{27}$ M. Maciejewski, Spojrzenie „w górę" $i$, wokoto” (Norwid - Malczewski), [w:] tegoż, Poetyka. Gatunek - obraz. W kręgu poezji romantycznej, Wrocław 1977; M. Maciejewski, Norwida Fatum ukrzyżowane, [w:] tegoż, „ażeby ciato powrócito w stowo”. Próba kerygmatycznej interpretacji literatury, Lublin 1991; M. Maciejewski, Norwidowskie „tagodne oko btękitu”, [w:] Liryka Cypriana Norwida, red. P. Chlebowski, W. Toruń, Lublin 2003. 
które powodują, że wiersz Norwida jawi się właśnie jako dzieło sztuki. Z takiego podejścia wypływa przenikliwe i adekwatne określenie specyficzności Norwida. Spójrzmy na jedno zdanie:

Zasadę kompozycyjną wyznacza tej liryce proces dochodzenia do prawdy, wydzieranie jej spod władzy ciemności, której ślady pozostają w chropawej składni, w zachwianym rytmie, w scjentyficznej metaforze.... ${ }^{28}$

Udatne proporcje znaczeń w tej syntezie, odpowiedniość krótkich formul, wychwytujących całe szeregi procesów zachodzących w tej poezji, dają świadectwo takiej lektury Norwidowego tekstu, która rozjaśnia tajniki utworu artystycznego i prowadzi w jego głębię.

Co to znaczy więc „,czytać Norwida”? Z o b a c z y ć t ę 1 i r y k ę j a k o d z i e ło s z t u k i, przedzierać się, czasami nie unikając pomyłek, w trudno uchwytne, (albo nieuchwytne) dla historii, gramatyki, nauki o języku rejony; drążyć to, co stanowi o s w o i s t o ś c i tej poezji, ponieważ chyba właśnie tam może dojść do najpełniejszego spotkania osoby podmiotu autorskiego (czynności twórczych, podmiotu tekstu) z osobą czytelnika: do „interpersonalnej wymiany”.

A co wiemy o liryce Norwida? Wiemy to, co opowiedzieli nam o wędrówkach w jej głąb czytelnicy najbardziej sprawni; ci, którzy wyznaczają szlaki i jednocześnie informują, że można iść dalej.

${ }^{28}$ M. Maciejewski, hasło: Liryka. Romantyzm, [w:] Literatura polska. Przewodnik encyklopedyczny, komitet red. J. Krzyżanowski i inni, Warszawa 1984, s. 577. 